
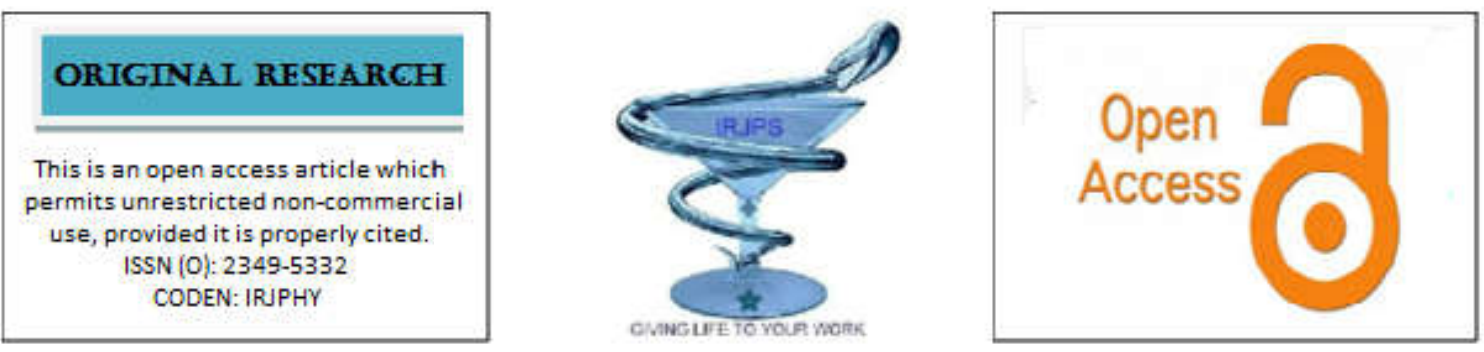

\title{
Formulation and invitro evaluation of novel gel containing liquid crystals of diclofenac in the treatment of arthritic disorders
}

\author{
Aswathy. B*, Shineabi, Vishnu. U, Mohammed Shaheem \\ Department of pharmaceutics, KTN College of Pharmacy, Chalavara, Puliyanamkunnu, Kerala
}

Submitted on: 18.06.2020; $\quad$ Revised on: 24.06.2020; $\quad$ Accepted on: 27.06.2020

\begin{abstract}
Present study was focused on the formulation and invitroevaluation of novel gel containing liquid crystalline gel. Aim of the study is to develop Diclofenac liquid crystalline gel for managing pain and inflammation using liquid crystalline form. The invitro release profile of the developed liquid crystalline gel was higher as compared to marketed and conventional gel. This is prepared by using tween 80 , cetosteryl alcohol and glycerol. Formulation LCG-1 to LCG-4 differs in the ratio of tween 80 and cetosteryl alcohol. Preformulation studies for pure drug were conducted andformulation was evaluated on the basis of viscosity, encapsulation efficiency and invitro drug release study using Franz diffusion cell. FTIR study of pure drug, polymer and the formulation proves there is no chemical interaction between them. Formulation LCG-3 had appropriate viscosity 1536.78, highest encapsulation efficiency $87.82 \pm 0.36$. Theinvitro release study found to have zero order release profile compare to all other formulation that indicates the predominant mechanism of drug release is diffusion. Invitro comparative evaluation of the liquid crystalline gel with that of 3 marketed samples (gel, emulgel and ointment) proves that liquid crystalline gel formulation has the sustained release capability compare to others.
\end{abstract}

KEY WORDS: Diclofenac, liquid crystalline gel, Tween 80, Cetostery alcohol

Corresponding author: Aswathy. B

\begin{tabular}{c}
\hline $\begin{array}{c}\text { Indian Research Journal of Pharmacy and Science; 25(2020)2266-2276; } \\
\text { Journal Home Page: https://www.irjps.in } \\
\text { DOI: } 10.21276 / \text { irjps.2020.7.2.18 }\end{array}$ \\
\hline
\end{tabular}




\section{INRODUCTION}

Diclofenac gel form is available in the market and can be used mainly for mild to moderate pain, rheumatoid arthritis, osteoarthritis. These formulations are available with short half-life. By adopting the drug, Diclofenac to a liquid crystalline form the half-life can be increased with sustained release action. Due to high viscosity of the liquid crystalline gel, the contact time of the drug with that of the infected areacan also increase.Diclofenac will inhibit prostaglandin synthesis which mediates poor patient compliance. So topical administration is an alternative method for Diclofenac oral administration,thus this formulation can be more effective in pain, rheumatoid arthritis $[1,2,4]$. Formulation developed for topical delivery must be pleasant to touch and feel it must not produce any irritation.

The goal of any drug delivery system is to provide a therapeutic amount of drug to the proper site in the body to promptly outcome of a drug. The common side effect of oral dose include abdominal pain,gastro intestinal bleeding,dizziness, head ache, swelling. The drug application to the skin mainly aims to prevent disorder, avoid first pass metabolism and to treat deep tissues such as muscles and vein [2]. This system of liquid crystalline gel show faster drug release compare to other gel, Emulgel, Ointment

A gel is a solid jelly-like material that can have properties ranging from soft and weak to hard and tough. Gels are defined as a substantially dilute cross- linked system, which exhibits no flow when in the steady- state.Liquid crystals (LCs) are matter in a state which has properties between those of conventional liquids and those of solid crystals. Liquid crystals can be divided in to Thermotropic,lyotropic and Metallotropic phase.

The characteristic orientation order of the liquid crystal state is between the traditional solid and liquid phases and this is the origin of the term mesogenic state.Thermotropic phases are those that occur in a certain temperature ranges. Many Thermotropic LCs exhibit a variety of phase as temperature is changed.lyotropic liquid crystal are of surfactant molecules. A lyotropic crystal consists of two or more component that exhibit liquidcrystalline properties in certain concentration ranges. Metallotropic Liquid is based on lowmelting inorganic phases [5].

\section{ADVANTAGE OF LIQUID CRYSTALLINE OVER GEL FORMULATION}

- These LC forms allow drug solubilisation with a proper choice of self-association structure.

- Both oil and water soluble drugs can incorporate and in high concentration.

- This will increase drug solubility, decrease drug degradation and to control drug release rate.

- Due to high viscosity this will provide the drug to highly localized in tissues

\section{METHODOLOGY}

\section{PREFORMULATION OF DICLOFENAC}

\section{Organoleptic property}

The drugwas visually inspected to find the organoleptic property like colourodour and appearance

\section{Determination of solubility of Diclofenac}

Excess drug $(100 \mathrm{mg})$ was added to $15 \mathrm{ml}$ of each fluid taken in a $25 \mathrm{ml}$ Stoppered conical flask and the mixtures were shaken for $24 \mathrm{hrs}$ at room temperature(28+-1) on rotary flask shaker. After 24 hours of shaking, $2 \mathrm{ml}$ sample were withdrawn at 2 hour interval and filtered immediately using a 0.45 disc filter. The filtered sample were diluted suitably and assayed for Diclofenac by measuring absorbance at $276 \mathrm{~nm}$. Shaking was continued until two consecutive estimations are the same.The solubility experiments were replicated four times each $(n=4)$.

\section{Melting point determination}

The melting point of Diclofenac was determined by using melting point apparatus. 


\section{Determination of partition coefficient}

$30 \mathrm{ml}$ of water and $30 \mathrm{ml} \mathrm{n}$-octanol solution were taken to the separating funnel. $100 \mathrm{mg}$ of drug(Diclofenac) was added to it and shaken for 1 hour. $1 \mathrm{ml}$ of aqueous layer was removed and transferred into a $100 \mathrm{ml}$ standard flask and made up to the mark with water. The absorbance was measured at $276 \mathrm{~nm}$ by using water as blank.

\section{UV spectroscopy:}

\section{Determination of $\lambda$ max}

Diclofenacwas accurately weighed and dissolved in distilled water to make $1 \mathrm{mg} / \mathrm{ml}$. The solution was then suitably diluted to $100 \mathrm{ml}$ using distilled water to get a final solution of concentration $100 \mu \mathrm{m} / \mathrm{ml}$. UV spectrum was recorded in the wavelength range 200-400nm.

\section{Preparation of calibration curve for Diclofenac}

Stock solution of Diclofenac $(100 \mu \mathrm{g} / \mathrm{ml})$ was prepared in water. The solution of Diclofenac was transferred into a series of $10 \mathrm{ml}$ volumetric flask up to the mark with water to get the concentration in the range of $10-50 \mu \mathrm{g} / \mathrm{ml}$. The absorbance of all the resulting solutions was measured at $276 \mathrm{~nm}$.

\section{FORMULATION OF DICLOFENAC LIQUID CRYSTALINE GEL}

Liquid crystals(LC) gel was prepared by melting cetosteryl alcohol and tween 80 together and water is added to approximately same temperature followed by cooling slowly and mixing at 500rpm stirrer.Diclofenac was mixed in mixture of cetosteryl alcohol and tween 80 and glycerol in different ratio [10].

Table 1: Formulation of Diclofenac liquid crystalline gel

\begin{tabular}{|l|c|c|c|c|c|}
\hline $\begin{array}{l}\text { SLN } \\
\text { CODE }\end{array}$ & $\begin{array}{c}\text { DRUG } \\
(\mathrm{mg})\end{array}$ & $\begin{array}{c}\text { TWEEN 80 } \\
(\mathrm{ml})\end{array}$ & $\begin{array}{c}\text { CETOSTEARYL ALCOHOL } \\
(\mathrm{mg})\end{array}$ & $\begin{array}{c}\text { GLYCEROL } \\
(\mathrm{ml})\end{array}$ & $\begin{array}{c}\text { WATER } \\
(\mathrm{ml})\end{array}$ \\
\hline LCG -1 & 100 & 5 & 5 & 0.5 & 15 \\
\hline LCG -2 & 100 & 2.5 & 7.5 & 0.5 & 15 \\
\hline LCG -3 & 100 & 7.5 & 2.5 & 0.5 & 15 \\
\hline LCG -4 & 100 & 5 & 10 & 0.5 & 15 \\
\hline
\end{tabular}

LCG -liquid crystalline gel

\section{COMPARISON OF LIQUID CRYSTALLINE GEL WITH MARKETED PRODUCTS}

compare vitro release study of liquid crystalline gel with the marketed formulation like (Gel, Emulgel, Ointment) These drugs are mainly used for the treatment of mild to moderate pain and treatment of osteoarthritis, rheumatoid arthritis .

\section{EVALUTAION OF GEL}

\section{Evaluation of Diclofenac gel pH and viscosity}

Amount of Diclofenac added during preparation of liquid crystalline gel

\section{I}

nvitro release study.

In vitro release studies of Diclofenac was performed in Franz diffusion cell that has receptor
The $\mathrm{pH}$ is measured using $\mathrm{pH}$ meter and viscosity by brook field viscometer[11].

\section{Determination of \%entrapment efficiency}

The $\%$ entrapment efficiency $(\% \mathrm{EE})$ of Diclofenac in LCG formulations were determined by centrifugation of the colloidal sample at $14000 \mathrm{rpm}$ at $25^{\circ} \mathrm{C}$ for $30 \mathrm{~min}$. The free Diclofenac in the supernatant is estimated by UV spectroscopy at 276nm [4]. compartment with an effective volume approximately $70 \mathrm{ml}$ and effective surface area of permeation of $3.14 \mathrm{sq} \mathrm{cms}$. The cellophane 
membrane was mounted between the donor and receptor compartment. A weighed amount of gel is placed on one side of the membrane; the receptor medium was phosphate buffer $\mathrm{pH}$ 7.4. The receptor compartment is surrounded by a water jacket to maintain the temperature at $37 \pm 0.5^{\circ} \mathrm{C}$. Heat is provided using a thermostatic hot plate with a magnetic stirrer. The receptor fluid is stirred by a Teflon coatedmagnetic bead fitted to a magnetic stirrer. At each sampling interval, sample is withdrawnand is measured at $276 \mathrm{~nm}$ [15].

\section{FTIR Spectra of Diclofenac sodium:}

IR spectra of physical mixture of drug and excipients were recorded by $\mathrm{KBr}$ method using Fourier Transform Infrared Spectrophotometer. A base line correction was made using dried potassium bromide pellet. The potassium bromidedrug pellet of approximately $1 \mathrm{~mm}$ diameter was prepared by grinding 3-5 $\mathrm{mg}$ of physical mixture of drug-excipients with 100-150 mg of potassium bromide in pressure compression machine. The sample pellet was mounted in IR compartment and scanned at wavelengths $4000 \mathrm{~cm}-1$ to $400 \mathrm{~cm}-1$

\section{RESULT AND DISCUSSION}

\section{FORMULATION AND EVALUATION OF LIQUID CRYSTALLINE GEL}

\section{Pre formulation studies of Diclofenac}

\section{Colour and appearance}

The formulation shows white in colour with semisolid consistency. It was observed that gel formulation shows good spread ability and viscosity.

\section{Organoleptic property}

Diclofenac drug is white to off white colour having bitter taste, odourless powder which is of hygroscopic and crystalline form

\section{Determination of solubility of Diclofenac}

The solubility of the received sample of clindamycin was examined in various solvents aqueous and organic. Diclofenac was freely soluble in water, slightly soluble in methanol and insoluble in chloroform.

\section{Melting point determination}

The melting point of pure Diclofenac was determined by melting point determining apparatus, and the melting point was found out to be $284^{\circ} \mathrm{c}$.

\section{Determination of Partition coefficient}

Partition coefficient of Diclofenac was determined by using water and n-octanol as solvents. It was found to be 13.1

\section{Determination of $\lambda \max$}

The $\lambda$ max of Diclofenac was determined by using UV spectrophotometer. The $\lambda \max$ was found to be $276 \mathrm{~nm}$.

Table 2:Calibration curve of Diclofenac

\begin{tabular}{|c|c|}
\hline Concentration(mcg/ml) & $\begin{array}{c}\text { Absorbance } \\
\text { at276nm }\end{array}$ \\
\hline 0 & 0 \\
\hline 1 & 0.033 \\
\hline 2 & 0.064 \\
\hline 3 & 0.0912 \\
\hline 4 & 0.123 \\
\hline 5 & 0.148 \\
\hline
\end{tabular}

Graph1:Calibration curve of Diclofenac

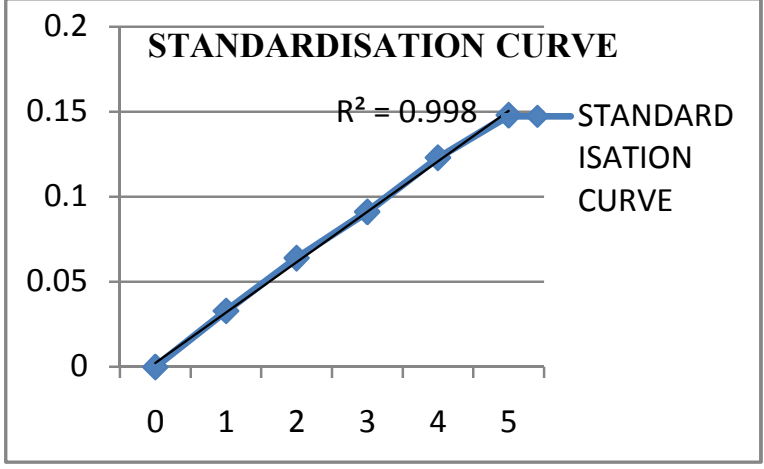




\section{EVALUATION TEST}

Table3: The formulations are subjected to various evaluation test and results are tabulated.

\begin{tabular}{|c|c|c|c|c|}
\hline S. NO & $\begin{array}{c}\text { Formulation } \\
\text { Code }\end{array}$ & PH & $\begin{array}{c}\text { Viscosity } \\
\text { (CPS) }\end{array}$ & $\begin{array}{c}\text { Encapsulation } \\
\text { Efficiency }\end{array}$ \\
\hline 1 & LCG-1 & 8.12 & 1354.67 & $85.46 \pm 0.15$ \\
\hline 2 & LCG-2 & 6.52 & 2132.45 & $95.32 \pm 0.3$ \\
\hline 3 & LCG-3 & 8.06 & 1536.78 & $87.80 \pm 0.36$ \\
\hline 4 & LCG-4 & 7.82 & 982.25 & $63.25 \pm 0.26$ \\
\hline
\end{tabular}

LCG -liquid crystalline gel

Table 4:In vitro release study(\%CDR of Diclofenac from liquid crystalline gel of best 3 formulation)

\begin{tabular}{|c|c|c|c|}
\hline Time & LCG-1 & LCG-2 & LCG-3 \\
\hline 1 & 0 & 0 & 0 \\
\hline 2 & 15.35 & 12.45 & 10.45 \\
\hline 3 & 30.62 & 25.34 & 18.67 \\
\hline 4 & 60.53 & 42.85 & 27.45 \\
\hline 5 & 75.82 & 60.21 & 42.85 \\
\hline 6 & 88.78 & 82.45 & 61.34 \\
\hline 7 & 92.63 & 88.36 & 72.45 \\
\hline 8 & 97.95 & 94.45 & 75.98 \\
\hline
\end{tabular}

LCG- liquid crystalline gel

Graph:2 In vitro drug release of diclofenac from liquid crystalline gel

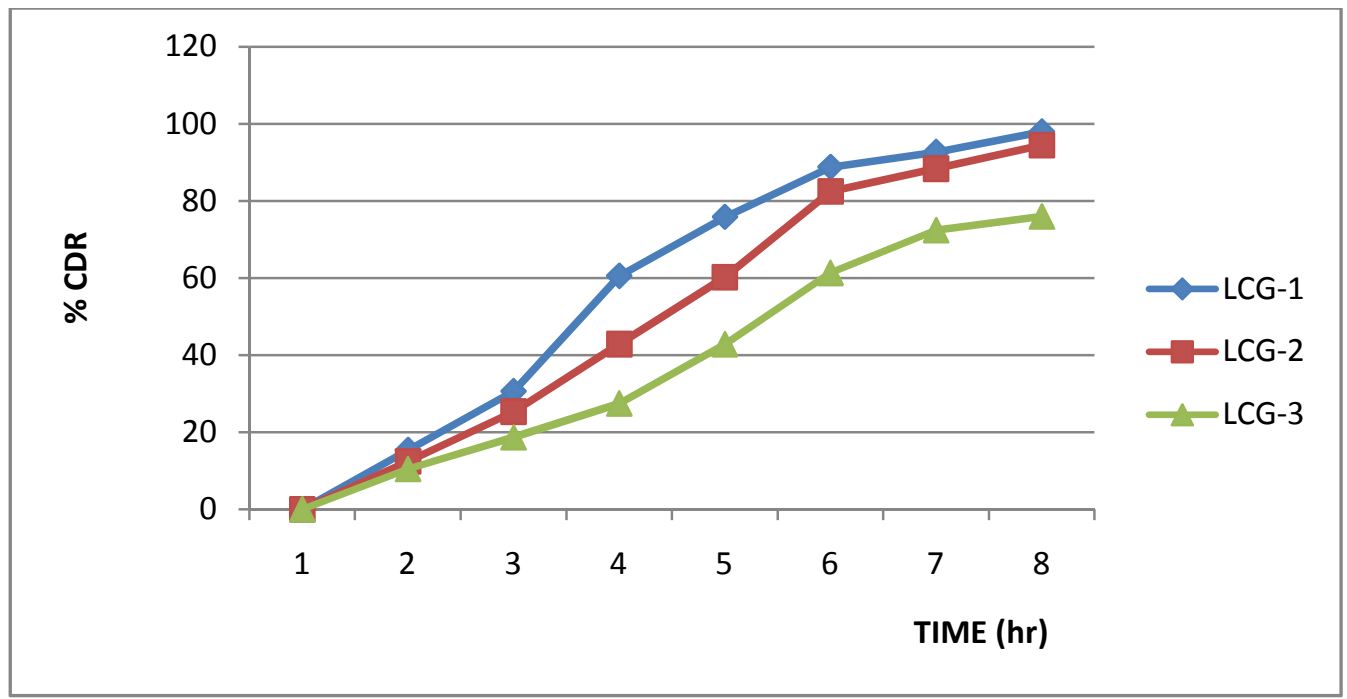




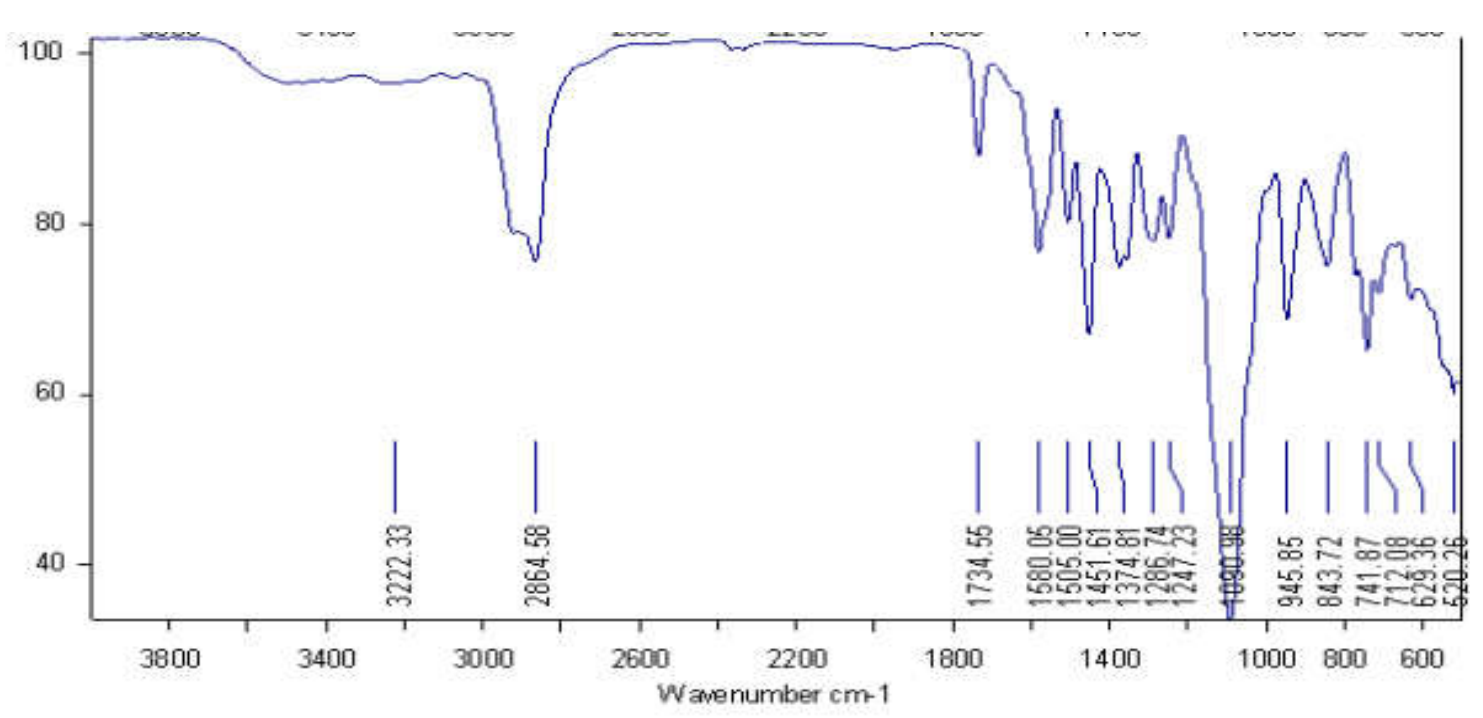

Figure-1 IR spectra ofDiclofenac LC gel form

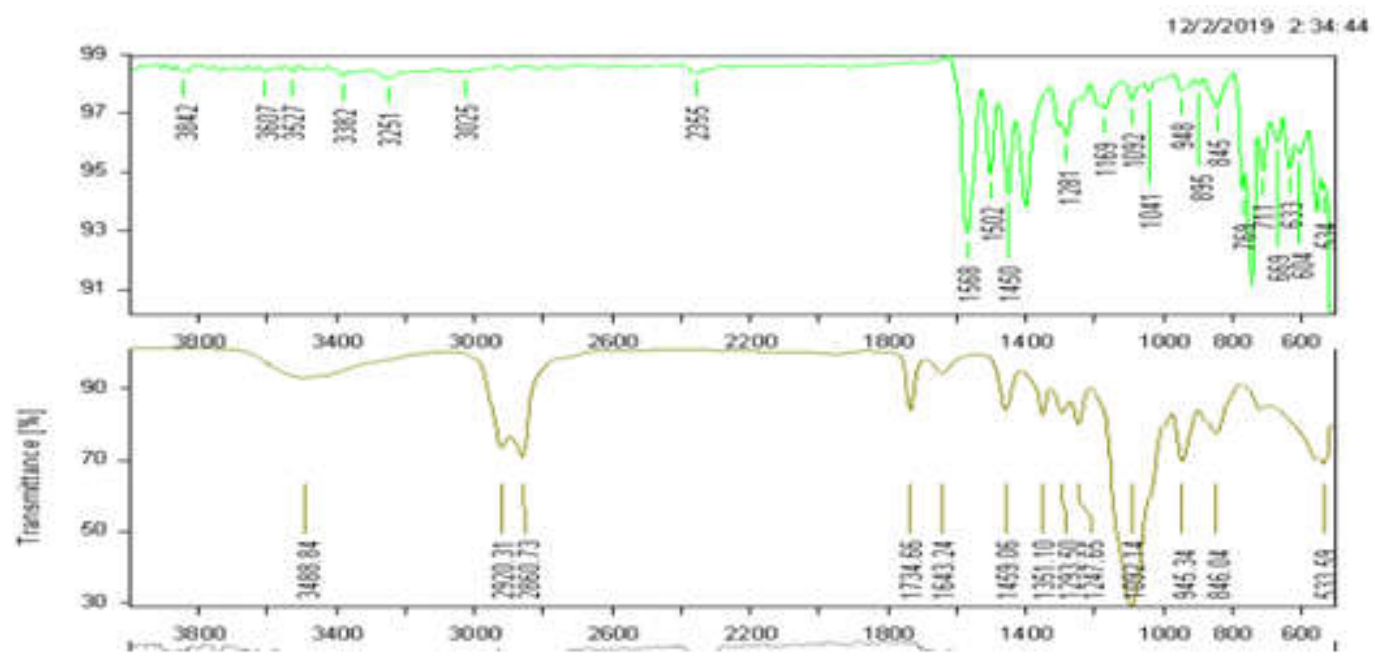

Figure -2 IR spectra of Diclofenac sodium pure drug, IR spectra of tween 80(polymer interactive study)

The FTIR spectra of Diclofenac, Tween 80 are depicted in figure(2). FTIR spectra of DiclofenacHCL figure (1) shows characteristic peaks at $1286 \mathrm{~cm}$ amide group, $741 \mathrm{~cm} \mathrm{C-}$ Clstretching, $1734 \mathrm{~cm}$ acid.

From the FTIR spectra of Diclofenac and the polymer it is evident that there is no chemical interaction between the drug and polymerin the formulation

\section{OPTIMIZATION OF BEST GEL}

Out of three formulations LCG-3 exhibited good release pattern. LCG-1releasesits $90 \%$ of drug with in $4 \mathrm{hr}$ and shows saturation effect. LCG-2 releases its $94 \%$ of drugin $8 \mathrm{hrs}$. LCG-3 releases only $75 \%$ of its drug in $8 \mathrm{hrs}$ and show sustained release. So LCG-3 had been optimized as the best formulation. To describe the exact mechanism and order of drug release, curve fitting analysis was done with LCG-3 


\section{CURVE FITING ANALYSIS}

1) Zero order kinetics

Table5 :Zero order kinetics of LCG3

\begin{tabular}{|c|c|c|}
\hline SI no & $\begin{array}{l}\text { TIME } \\
(\text { HRS })\end{array}$ & $\begin{array}{c}\text { LCG-3 } \\
\text { \%CDR }\end{array}$ \\
\hline 1 & 0 & 0 \\
\hline 2 & 1 & 10.45 \\
\hline 3 & 2 & 18.67 \\
\hline 4 & 3 & 27.45 \\
\hline 5 & 4 & 42.85 \\
\hline 6 & 5 & 61.34 \\
\hline 7 & 6 & 72.45 \\
\hline 8 & 7 & 75.98 \\
\hline
\end{tabular}

Graph3: zero order kinetics of LCG-3

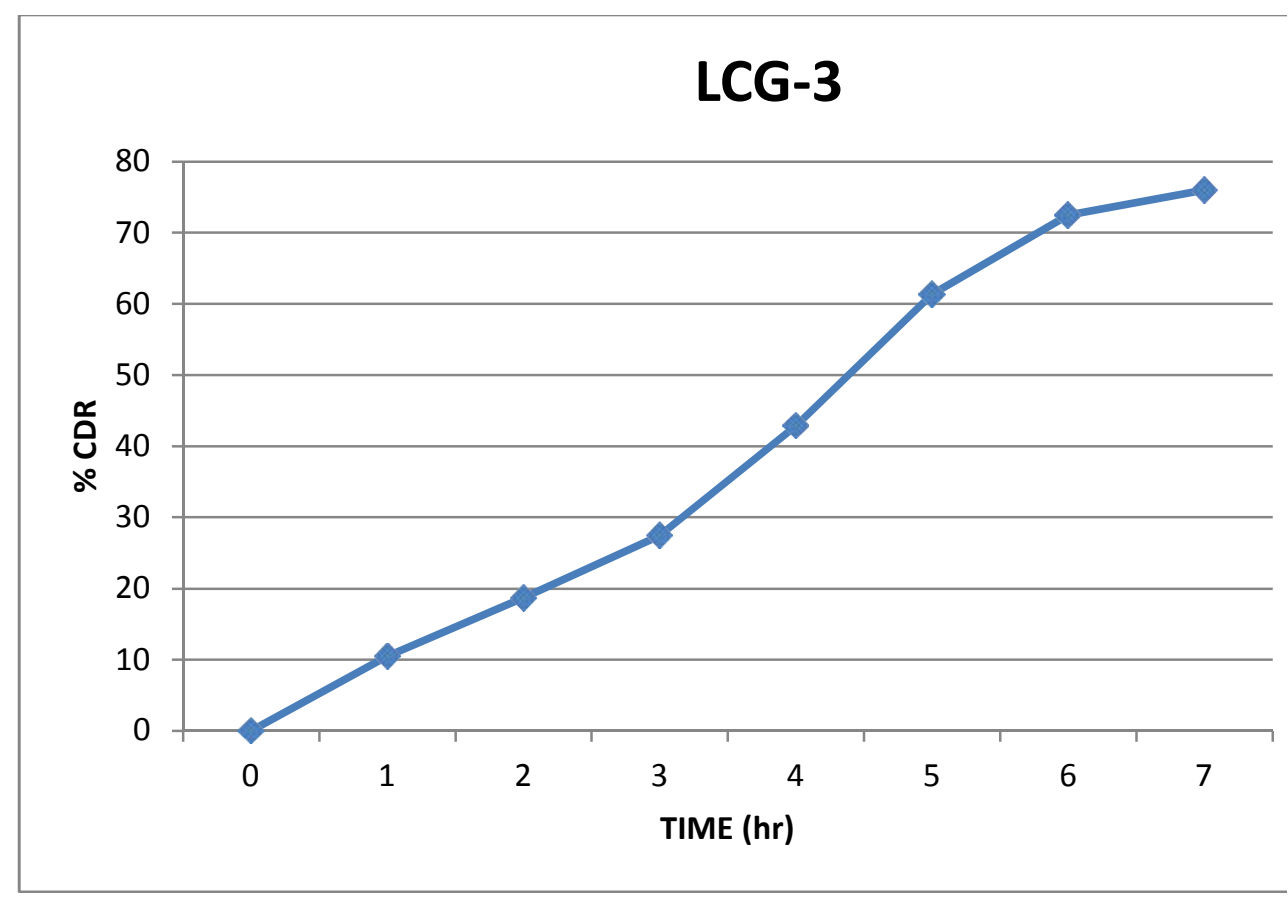


2) First order kinetics

Table6: First order kinetics of LCG3

\begin{tabular}{|c|c|c|}
\hline Slno & $\begin{array}{c}\text { Time } \\
\text { (HRS) }\end{array}$ & $\begin{array}{c}\text { Log \% CDR } \\
\text { LCG-3 }\end{array}$ \\
\hline 1 & 0 & 0 \\
\hline 2 & 1 & 1.019 \\
\hline 3 & 2 & 1.271 \\
\hline 4 & 3 & 1.438 \\
\hline 5 & 4 & 1.631 \\
\hline 6 & 5 & 1.787 \\
\hline 7 & 6 & 1.860 \\
\hline 8 & 7 & 1.880 \\
\hline
\end{tabular}

Graph4: first order kinetics

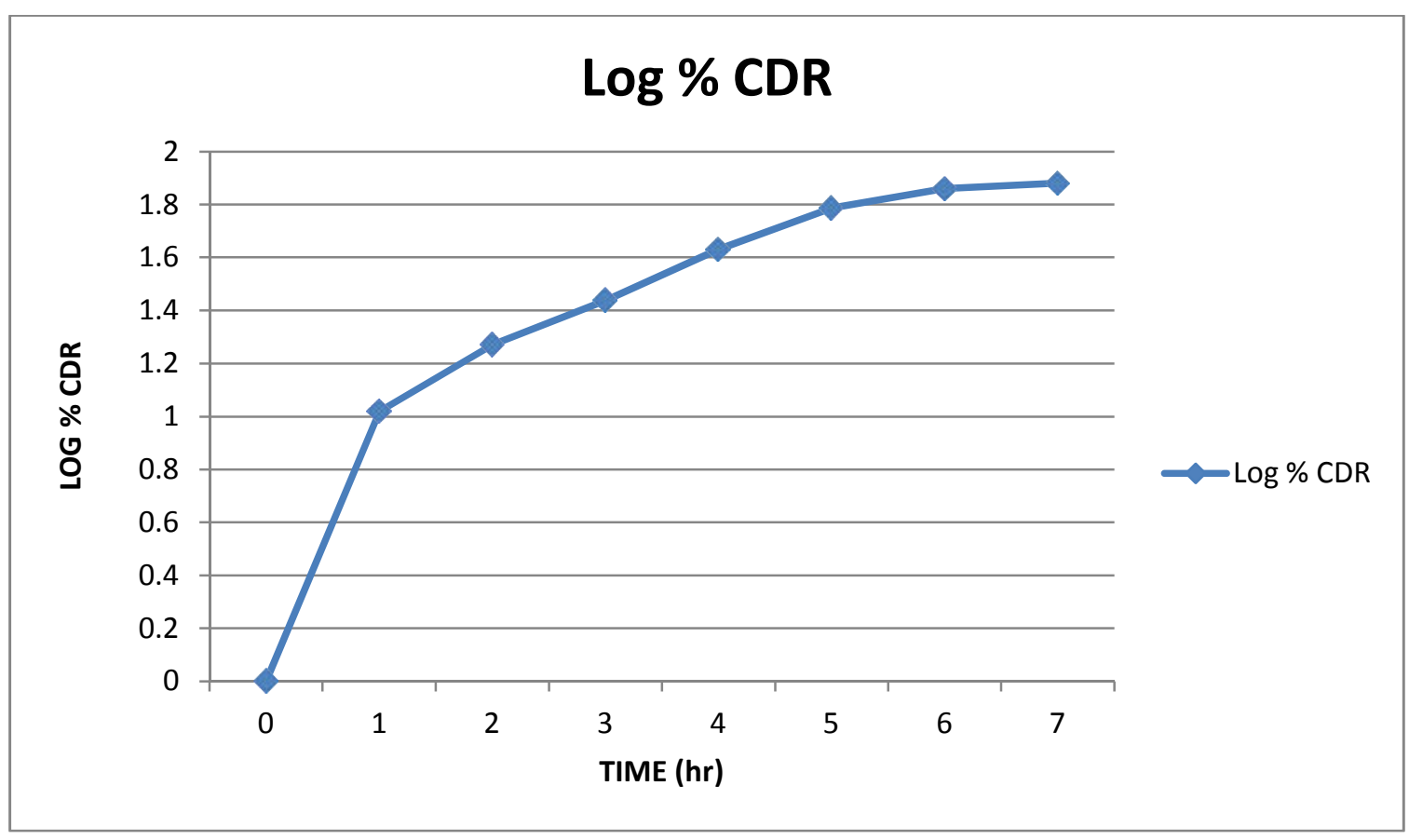




\section{3) Higuchi model}

Table7: Higuchi model LCG3

\begin{tabular}{|c|c|c|}
\hline SI no & $\begin{array}{c}\text { Square root } \\
\text { time }\end{array}$ & $\begin{array}{c}\text { LCG-3 } \\
\text { \%CDR }\end{array}$ \\
\hline 1 & 0 & 0 \\
\hline 2 & 1 & 10.45 \\
\hline 3 & 1.414214 & 18.67 \\
\hline 4 & 1.732051 & 27.45 \\
\hline 5 & 2 & 42.85 \\
\hline 6 & 2.236068 & 61.34 \\
\hline 7 & 2.44949 & 72.45 \\
\hline 8 & 2.645 & 75.98 \\
\hline
\end{tabular}

Graph5: Higuchi model LCG-3

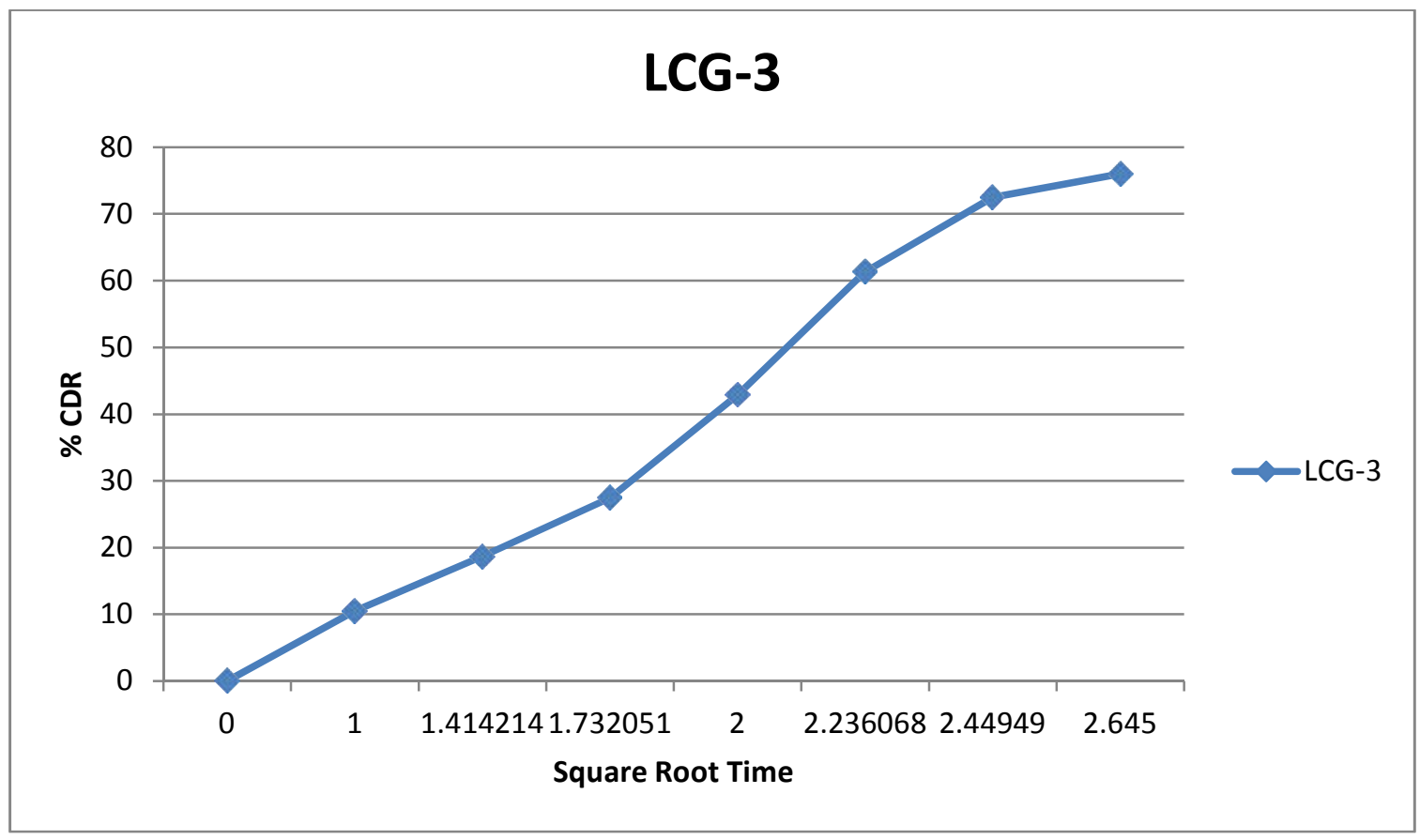


Table8: Invitro comparison of formulated drug with marketed formulations.

\begin{tabular}{|c|c|c|c|c|}
\hline TIME & LC-GEL & OINTMENT & NORMAL GEL & EMULGEL \\
\hline 1 & $\mathbf{0}$ & $\mathbf{0}$ & $\mathbf{0}$ & $\boldsymbol{0}$ \\
\hline 2 & $\mathbf{1 0 . 4 5}$ & $\mathbf{1 0 . 4 3}$ & $\mathbf{1 2 . 3 2}$ & $\mathbf{1 1 . 4 5}$ \\
\hline 3 & $\mathbf{1 8 . 6 7}$ & $\mathbf{2 2 . 5 3}$ & $\mathbf{2 4 . 5 2}$ & $\mathbf{2 3 . 2 2}$ \\
\hline 4 & $\mathbf{2 7 . 4 5}$ & $\mathbf{4 0 . 6 2}$ & $\mathbf{3 8 . 5 6}$ & $\mathbf{3 4 . 6 1}$ \\
\hline 5 & $\mathbf{4 2 . 8 5}$ & $\mathbf{5 8 . 9 2}$ & $\mathbf{4 6 . 2 2}$ & $\mathbf{4 7 . 3 3}$ \\
\hline 6 & $\mathbf{6 1 . 3 4}$ & $\mathbf{7 8 . 3 5}$ & $\mathbf{6 3 . 7 2}$ & $\mathbf{6 4 . 3 2}$ \\
\hline 7 & $\mathbf{7 2 . 4 5}$ & $\mathbf{8 7 . 3 6}$ & $\mathbf{7 8 . 9 2}$ & $\mathbf{7 6 . 5 4}$ \\
\hline 8 & $\mathbf{7 5 . 9 8}$ & $\mathbf{9 3 . 4 5}$ & $\mathbf{8 9 . 3 3}$ & $\mathbf{8 4 . 3 5}$ \\
\hline
\end{tabular}

\section{Graph6: Invitro comparison of formulated drug with marketed formulations}

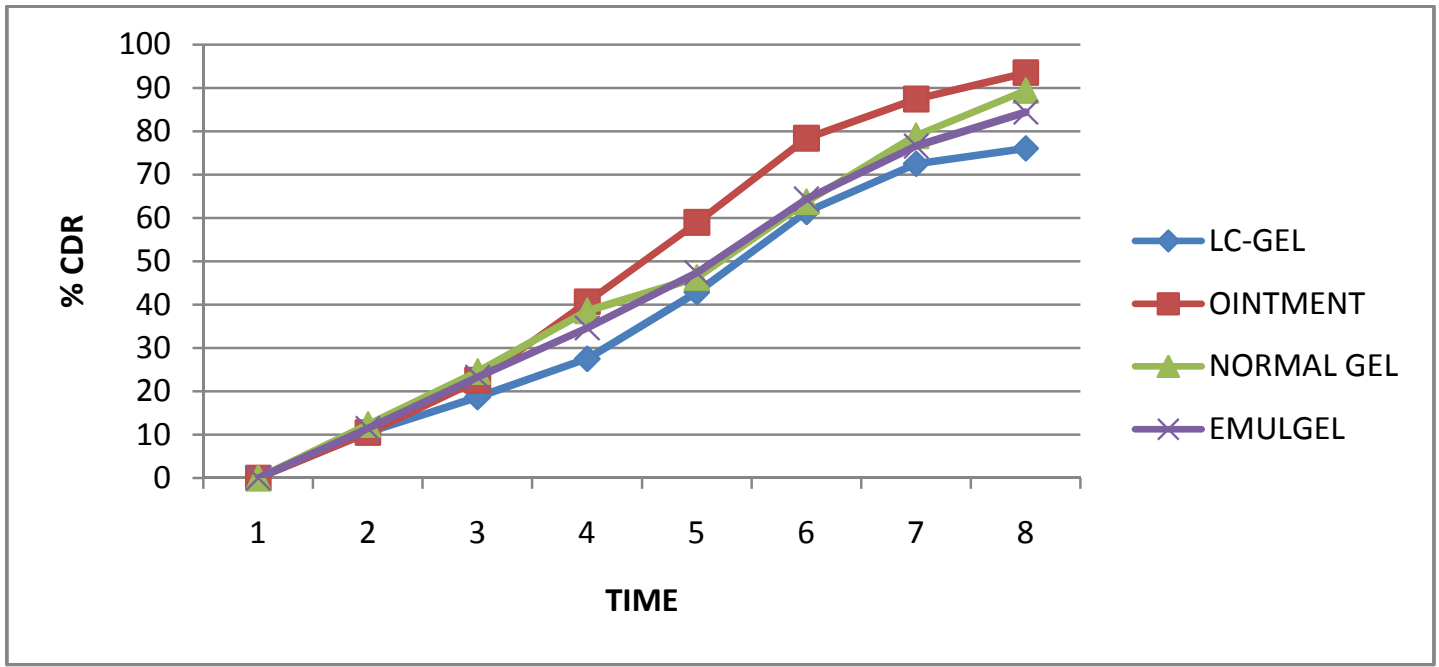

\section{DISCUSSION}

\section{Preformulation studies}

Preformulation studies were carried out and the drug was found to be white to off white crystalline powder which is hygroscopic in nature. The drug was found to be odourless bitter in taste. Considering solubility, the drug is freely soluble in water. From FTIR studies proves there is no chemical interaction between drugs and polymer

\section{Liquid crystalline gel}

Liquid crystalline was prepared from the formulation and whose encapsulation efficiency was determined. The LCG2 have encapsulation ability (EE) $95.32 \%$ and LCG3 have EE $87.80 \%$. For more optimizing the invitro release study was
conducted.LCG2 haveinvitro release of $94.45 \%$ in about 8 hours.LCG3 release only $75 \%$ of drug in 8 hours. LCG2 was not suitable for inserting gel into cosmetic cream because of high viscosity.SoLCG3 has been optimized as the best formulation. The invitro release profile of liquid crystalline gel Vs marketed products are plotted by time in $\mathrm{x}$ axis and $\% \mathrm{CDR}$ in y axis.Invitro comparison of the sample with that of marketed product founds that liquid crystalline formulation has sustained action compares to other formulation

\section{CONCLUSION}

The preformulation studies were performed using the pure drug found to be useful for the formulation. The formulation was prepared using fusion method. The formulation were subjected to evaluation procedures and found that this 
formulation was have sustained releasing ability of about $75.98 \%$ in 8 hour. This is also having high encapsulation efficiency.

Zero order plot of optimized formulation (G3) indicated that the release mechanism is concentration independent $(\mathrm{R}=0.995)$. Higuchi's plot for the formulation revealed that the predominant mechanism of drug release is $\operatorname{diffusion}(\mathrm{R}=0.898)$.

Optimized formulation shows sustained action compares to other 3 marketed formulations.

\section{BIBILOGRAPHY}

1. Zochling J. Bohl-buhler M.H.J; Bavaliakos x , Feldtkeller, Braunj. Non steroidalanti inflammatory drug use in alkylosing spondylitis - a population based survy.clin.rheumatol, 2006;25(6) 794-800.doi $10.1007 / \mathrm{s} 10067-005-0132 \mathrm{y}$ [pubmed]

2. Gan TJ. Diclofenac . an update of its mechanism of action and safety profile.curr med res opin .2010;26 (7): 1715-1731 doi.10.1185/03007995.2020.486307

3. SehtBL.comparative pharmacokinetics and bioavailability study of percutaneous absortion of diclofinac from topical formulation containing drug as a solution gel or as an emulsion gel ArzneimittelJes schang.1992;92(2)120-122.

4. Demiana ,Nesseem formulation and evaluation of irtaconazole via liquid crystals for topical delivery journels of pharmaceuticals and biomedical analysis 26(3), 387-399, 200.

5. T. Kato, Y Hirai, S Nakaso, M Moriayama preparation of liquid crystalline physical gel, society reviews, 2007-pubs.rsc.org

6. Gupta A, Mishra AK, Sing AK, Gupta V,Bansal P. Formulation and evaluation of topical gel of diclofenac sodium from different polymer. Drug invention today 2010;2(5):250 253

7. Keisuke Yamanda, Jun Yamakshita at al. preparation and evaluation of liquid crystal formulation with skin permeation- enhancing abilities for entrapped drug. Jan2011. Journal of oleoscience $\quad 60(1) ; 31-40$

Doi:10.5650/jos.60.31

8. WesamRadhiKadhumShohaiSekiguchi, IchroHijikuko, hiroakitodo, kenjisugibayashi, a noval chemical enhancer approach for trans dermal drug delivery with $\mathrm{C}_{17^{-}}$Monoglycerol ester liquid crystal - forming lipid medicine , material science, drug delivery 2019

9. MoloundKazem, JaleshVarshosaz, MajidTabbakhian. Preparation and evaluation of lipid based liquid crystalline formulation of fenofibrate- advanced biomedical research 2018

10. Eccleston, G.m; beattie,L; Microstructural changes during the storage of system containing cetosteryl alcohol / polyoxyethylene alkyl ester surfactant. Drug Dev.Ind pharm 14; 2499-2518 1988

11. Kumar, R., Katare, OP., Lecithineorganogels as a potential phospholipid structural system for topical drug delivery.

12. USP XXV, US pharmacopeial convention Rockville, MD. PP.1662-1663,2003

13. Makai, M, Csanyi, E., Dekany, I., Nemeth, Z., Eros, I., Structural properties of non-ionic surfactant / glycerol/ paraffin lyotropiccrystals. Colloid polym.sci.281, 839-844, 2003

14. Omray, 1.k., Kohli, S., Khopade, AJ.,patil, S., Gajbhiye, asmith., agrawal,G.P. Government of mesophicmicroreservoir based trans dermal delivery of propranolol Indian J.pharm.sci.70,578-584,2008

15. Mueller-Goymann, CC., Physiochemical characterization of colloidal drug delivery system such as reverse micelles vesicles, liquid crystals and nano particles for topicl administrations. Eur.J.Pharm. Biopharm.58,343-356,2004

16. Hussain,A., Pina, A.S., Roque, A.C.A biorecognization and detection using liquid crystals. Biosens. Bioelectron.25, 1-8, 2009

17. Guy, R.H., Hadgrft, J. Physiochemical aspects of percutaneous penetration enhancement pharm.Res.5,753-758,1988 